\title{
Implementasi Metode Glenn Doman dalam Meningkatkan Kemampuan Membaca Siswa Kelas I SD Negeri Bojong Kecamatan Cikatomas Kabupaten Tasikmalaya Tahun Pelajaran 2018/2019
}

\author{
Resi Indah Budiarti ${ }^{1}$, Dedi Heryadi ${ }^{2}$, Riga Zahara Nurani ${ }^{3}$ \\ 1,3 Universitas Perjuangan Tasikmalaya, Universitas Pendidikan Indonesia \\ resiindah@gmail.com
}

\section{Article History}

accepted 2/11/2019

approved 23/11/2019

published 31/12/2019

\begin{abstract}
This Research is motivated by reading difficulties experienced by students of class I SD Negeri Bojong Cikatomas Kota Tasikmalaya, the number of first grade students of SD Negeri bojong 2018/2019 academic year 15 students of 7 girls and 8 boys, two of whom have difficulty reading. The purpose of this study was to improve the reading ability of first grade students at Bojong State Elementary School through the Glenn Doman method which uses flash cards made of cardboard with a size of $15 \times 50 \mathrm{~cm}$. This type of research is a classroom action research conducted three cycles. S. Every cycle there are four stages, namely the stages of planning, implementation, observation, and reflection. The technique used in this study was observation of Bojong State Elementary School students, and interviews conducted with various parties including with class I teachers, all grade I students, and principals of Bojong State Elementary School. The results of the research through the Glenn Doman method showed an increase in reading of each cycle experienced by students of grade 1 at SD Negeri Bojong, each cycle there were four stages. The average score obtained in the first cycle was 3.03, second cycle was 3.2, and third cycle was 3.5. So the Glenn Doman method is able to increase the reading difficulties experienced by first grade students of Bojong State Elementary School, Cikatomas Subdistrict, Tasikmalaya District.
\end{abstract}

Keywords: Difficulty, reading, G lenn D oman method

\begin{abstract}
Abstrak
Penelitian ini dilatarbelakangi oleh kesulitan membaca yang dialami siswa kelas I SD Negeri Bojong Kecamatan Cikatomas Kabupaten Tasikmalaya, jumlah siswa kelas I SD Negeri bojong tahun pelajaran 2018/2019 15 siswa 7 siswa perempuan dan 8 siswa laki-laki, dua diantaranya mengalami kesulitan membaca. Tujuan penelitian ini adalah untuk meningkatakan kemampuan membaca terhadap siswa kelas I SD Negeri Bojong melalui metode Glenn Doman yang menggunakan media berupa flash card yang terbuat dari kertas karton dengan ukuran $15 \times 50 \mathrm{~cm}$. Jenis penelitian yang digunakan adalah penelitian tindakan kelas yang dilaksanakan tiga siklus. Setiap siklus ada empat tahapan yaitu tahapan perencanaan, pelaksanaan, pengamatan, dan refleksi. Teknik yang dilakukan dalam penelitian ini adalah observasi terhadap siswa SD Negeri Bojong, dan wawancara yang dilakukan dengan berbagai pihak diantaranya dengan guru kelas I, seluruh siswa kelas I, dan kepala sekolah SD Negeri Bojong. Hasil penelitian melalui metode Glenn Doman menunjukkan adanya peningkatan membaca dari setiap siklus yang dialami siswa kelas I SD Negeri Bojong, setiap siklus ada empat tahapan. Skor rata-rata yang di peroleh pada siklus I 3,03, siklus II 3,2, dan siklus III 3,5. Jadi metode Glenn Doman mampu meningkatkan kesulitan membaca yang dialami siswa kelas I SD Negeri Bojong kecamatan cikatomas kabupaten tasikmalaya.
\end{abstract}

Kata kunci : Kesulitan, membaca, metode Glenn Doman

Social, Humanities, and Education Studies (SHEs): Conference Series https://jurnal.uns.ac.id/shes

p-ISSN 2620-9284 e-ISSN 2620-9292 


\section{PENDAHULUAN}

Kemampuan membaca yang dialami siswa berbeda-beda, ada yang sudah mampu membaca dan ada juga yang belum mampu membaca. Berdasarkan penelitian yang dilakukan, siswa kelas 1 SD Negeri Bojong mengalami kesulitan membaca, Adapun upaya untuk mengatasi permasalahan kesulitan membaca yaitu dengan menggunakan metode Glenn Doman.

Membaca merupakan suatu proses decoding, yakni mengubah kode-kode atau lambang-lambang verbal yang berupa rangkaian huruf-huruf menjadi bunyi-bunyi bahasa yang dapat dipahami. Proses pengubahan lambang menjadi bunyi berarti disebut proses decoding (proses pembacaan sandi). Membaca merupakan rekontruksi makna dari bahan-bahan cetak (Nafi'ah, 2018 : 40). Membaca adalah suatu proses yang dilakukan serta dipergunakan oleh pembaca untuk memperoleh pesan yang hendak disampaikan oleh penulis melalui media kata-kata atau bahasa tulis (Tarigan, $2013: 7)$.

Berdasarkan pendapat para ahli maka dapat disimpulkan bahwa membaca merupakan suatu ucapan yang diucapkan oleh seseorang melalui huruf atau tulisan menjadi bunyi sehingga memperoleh informasi, pesan, serta pengetahuan yang belum diketahui oleh pembaca.

Metode Glenn Doman adalah metode mengajar anak-anak untuk membaca dan mengenali huruf dengan menggunakan kartu flash sehingga siswa akan memiliki kemampuan untuk percaya diri dan imajinatif (Ahmadi : 2010). Metode ini dirancang untuk membuat para guru, orang tua atau anak-anak mereka mengetahui dan memahami hal-hal yang ada di sekitar mereka. Adapun tujuan penelitian yaitu:

1. Menjelaskan perencanaan metode Glenn Doman terhadap siswa kelas I SD Negeri Bojong yang mengalami kesulitan membaca.

2. Menjelaskan implementasi metode Glenn Doman terhadap siswa kelas I SD Negeri Bojong yang mengalami kesulitan membaca.

3. Menjelaskan hasil kemampuan membaca siswa kelas I SD Negeri Bojong melalui metode Glenn Doman.

Metode Glenn Doman adalah salah satu bentuk stimulasi yang dapat diberikan untuk meningkatkan perkembangan anak, terutama perkembangan bahasa dan kognitif. Metode Glenn Doman yang diberikan yaitu flash card dan dot card ( Eko, Wibowo : 2014).

Berdasarkan pendapat para ahli maka dapat disimpulkan bahwa metode Glenn Doman merupakan metode pembelajaran untuk mengatasi kesulitan membaca yang dialami siswa dengan menggunakan media berupa flash card.

\section{METODE}

Metode penelitian yang digunakan peneliti adalah Penelitian Tindakan Kelas (PTK). Penelitian tindakan kelas adalah penelitian yang mengkombinasikan prosedur penelitian dengan tindakan substansi, suatu tindakan yang dilakukan dalam displin inkuiri, atau suatu usaha seseorang untuk memahami apa yang sedang terjadi, sambil terlihat dalam sebuah proses perbaikan dan perbaikan Hopkins dalam Wiriatmaja (2014 : 11).

Langkah-langkah PTK menurut Kemmis dan Mc Taggart :

1. Refleksi awal

2. Penyusunan perencanaan

3. Pelaksanaan tindakan.

4. Observasi (Pengamatan)

5. Refleksi akhir 
Populasi dan sasaran dalam penelitian adalah siswa kelas I SD Negeri Bojong Kecamatan Cikatomas Kabupaten Tasikmalaya.

Salah satu teknik pengumpulan data yang tidak hanya mengukur sikap dari responden (wawancara dan angket) namun juga dapat digunakan untuk merekam berbagai fenomena yang terjadi (situasi, kondisi) (Sugiyono, 2014 : 231). Adapun teknik yang digunakan dalam penelitian sebagai berikut.

1. Tes.

2. Observasi

3. Wawancara

\section{HASIL DAN PEMBAHASAN}

Data hasil penelitian yang dikumpulkan adalah data yang berhubungan dengan masalah penelitian. Dengan melakukan penelitian terhadap objek dan subjek maka dilakukan penelitian tiga siklus. Adapun skor rata-rata dari tiga siklus sebagai berikut:

Tabel 1. Skor Rata-rata Siswa

\begin{tabular}{|c|c|c|}
\hline No & Nama Siswa & Skor \\
\hline 1. & AAP & 4 \\
\hline 2. & AS & 3 \\
\hline 3. & $\mathrm{AA}$ & 3 \\
\hline 4. & $\mathrm{AH}$ & 3 \\
\hline 5. & A & 4 \\
\hline 6. & $\overline{\mathrm{AA}}$ & 3 \\
\hline 7. & DM & 3 \\
\hline 8. & DN & 3 \\
\hline 9. & FS & 4 \\
\hline 10. & JP & 4 \\
\hline 11. & KAP & 4 \\
\hline 12. & $\mathrm{NHH}$ & 2 \\
\hline 13. & $\mathrm{NI}$ & 3 \\
\hline 14. & S & 3 \\
\hline 15. & TAA & 4 \\
\hline \multicolumn{2}{|r|}{ Total Skor } & 50 \\
\hline \multicolumn{2}{|r|}{ Rata-rata } & 3,33 \\
\hline
\end{tabular}

Berdasarkan skor rata-rata siswa yaitu 3,33 maka dapat disimpulkan bahwa siswa mengalami peningkatan, skor 3,33 di sebut juga dengan siswa sudah mampu membaca sehinggan implementasi metode Glenn Doman dikatakan mampu meningkatkan kesulitan membaca yang dialami siswa kelas I SD Negeri Bojong.

Selain dilaksanakan tiga siklus peneliti juga melaksanakan observasi terhadap siswa SD Negeri bojong dan wawancara terhadap siswa kelas I, guru kelas I, dan kepala SD Negeri Bojong. Melalui tiga siklus yang dilaksanakan, siswa mengalami peningkatan kemampuan membaca melalu metode Glenn Doman, respon siswa terhadap metode Glenn Doman sangat baik. Siswa menjadi lebih semangat ketika melaksanakan kegiatan pembelajaran dengan menggunakan metode Glenn Doman. Skor rata-rata siswa

Hasil penelitian setiap siklus meningkat. Adapun peningkatan yang dialami siswa disetiap siklus berbeda-beda, ada yang meningkat drastis dan ada juga yang meningkat secara perlahan, hal tersebut terjadi karena motivasi yang ada pada diri siswa berbeda. Selain dilaksanakan proses pembelajaran melalui tiga siklus peneliti 
4th National Seminar on Guidance and Counseling (SNBK 2019) and Workshop on

Pedagogical Theory and Practice (WTPP 2019)

SHEs: Conference Series 2 (2) (2019) $131-136$

juga menggunakan instrument penelitian berupa wawancara dengan guru kelas I, siswa kelas I, dan kepala sekolah.

Adapun selain wawancara peneliti juga melakukan observasi terhadap kegiatan pembelajaran siswa di dalam kelas pembelajaran dari mulai siklus I, siklus II, dan siklus III.

Dalam observasi terhadap siswa ada beberapa aspek diantaranya:

1. Aktivitas siswa di dalam kelas

2. Ketertiban siswa selama proses pembelajaran dengan menggunakan metode Glenn Doman

3. Sikap siswa ketika guru mengajar dengan menggunakan metode Glenn Doman

4. Respon siswa ketika guru menyuruh membaca tulisan yang ada di flash card

5. Hasil belajar siswa melalui metode Glenn Doman

Setiap siklus melaksanakan pembelajaan sesuai dengan langkah-langkah metode Glenn Doman yang menggunakan media berupa flash card melalui empat tahapan, dimana hasil dari empat tahap yang dilakukan di setiap siklus diperoleh nilai peningkatan rata-rata siklus I, II, dan III pada tahap I, II, III, dan IV disetiap siklus diantaranya :

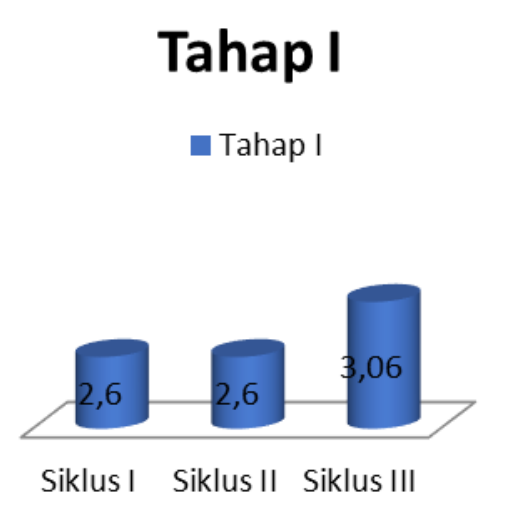

Gambar 1. Peningkatan Rata-rata Siklus I, II, III Tahap 1

Berdasarkan gambar 1 peningkatan pada tahap I setiap siklus mengalami peningkatan, nilai rata-rata yang dihasilkan di siklus I 2,6, siklus II 2,6, dan siklus III 3,06.



Gambar 2. Peningkatan Rata-rata Siklus I, II, III Tahap I1 
4th National Seminar on Guidance and Counseling (SNBK 2019) and Workshop on

Pedagogical Theory and Practice (WTPP 2019)

SHEs: Conference Series 2 (2) (2019) $131-136$

Berdasarkan gambar 2, peningkatan pada tahap II setiap siklus mengalami peningkatan, nilai rata-rata yang dihasilkan di siklus I 2,93, siklus II 2,93, dan siklus III 3,6 .

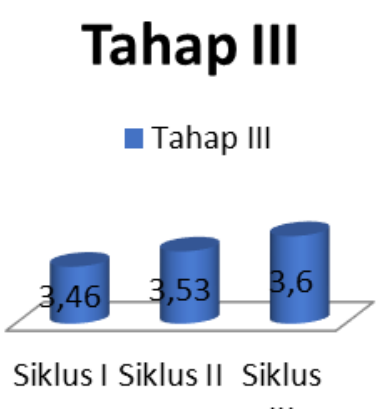

III

\section{Gambar 3 Peningkatan Rata-rata Siklus I, II, III Tahap I1I}

Berdasarkan gambar 3 peningkatan pada tahap III setiap siklus mengalami peningkatan, nilai rata-rata yang dihasilkan di siklus I 3,46, siklus II 3,53, dan siklus III 3,6 .

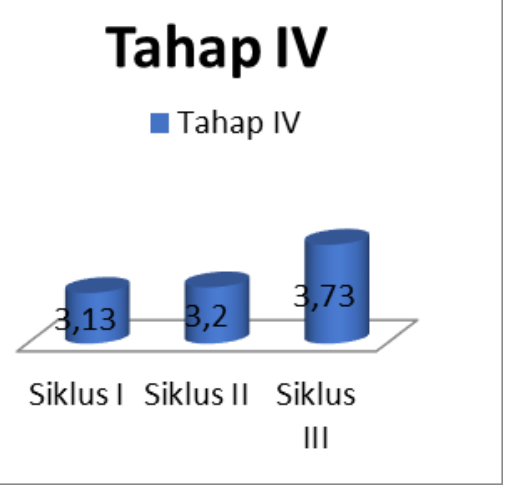

\section{Gambar 4 Peningkatan Rata-rata Siklus I, II, III Tahap IV}

Berdasarkan gambar 4 peningkatan pada tahap IV setiap siklus mengalami peningkatan, nilai rata-rata yang dihasilkan di siklus I 3,13, siklus II 3,2, dan siklus III 3,73 .

\section{SIMPULAN}

Berdasarkan hasil penelitian yang dilakukan di kelas I SD Negeri Bojong, Kecamatan Cikatomas, Kabupaten Tasikmalaya tahun ajaran 2018/2019 melalui analisis data dan pembahasan yang dijelaskan pada bab sebelumnya maka diperoleh hasil serta jawaban dari rumusan masalah dalam penelitian, yaitu penggunaan metode Glenn Doman dapat meningkatkan kemampuan membaca pada siswa kelas I SD Negeri bojong. Peningkatan yang dialami siswa SD Negeri Bojong baik, karena dengan penerapan metode Glenn Doman menambah rasa percaya diri dan motivasi dalam diri siswa sehingga siswa antusias dalam melaksanakan pembelajaran.

Pembelajaran menggunakan metode Glenn Doman dapat meningkatkan kemampuan membaca pada siswa kelas rendah khususnya siswa kelas I. Hal tersebut dapat terlihat dari observasi yang dilakukan peneliti untuk mengetahui peningkatan 
4th National Seminar on Guidance and Counseling (SNBK 2019) and Workshop on

Pedagogical Theory and Practice (WTPP 2019)

SHEs: Conference Series 2 (2) (2019) $131-136$

kemampuan membaca yang dialami siswa kelas I SD Negeri Bojong, dengan demikian metode Glenn Doman bukan hanya meningkatkan kemampuan membaca tetapi juga meningkatkan motivasi pada diri siswa.

\section{DAFTAR PUSTAKA}

Ahmadi F. (2010). Meningkatkan Minat Membaca Siswa Sekolah Dasar dengan Metode Glenn Doman Berbasis Multimedia. Jurnal Penelitian Pendidikan (JPP). Vol 27, No 12010 . Semarang: Universitas Negeri Semarang.

Eko, Wibowo. (2014). Pengaruh Metode Glenn Doman Terhadap Perkembangan Bahasa dan Koginitif Anak Usia Pra Sekolah di TK Ladas Berendai Prabumulih. Jurnal Program Studi PGMI, Vol 1 No 2 (2014) : September. Prabumulih : JP Keperawatan

Nafi'ah, siti A. (2018). Mode-Model Pembelajaran Bahasa Indonesia di SD/MI. Depok:AR-RUZZ MEDIA.

Sugiyono. (2014). Metode Penelitian Kualitatif dan Kuantitatif $R$ \& $D$. Bandung: Alfabeta.

Tarigan, Henry G. (2013). Membaca Sebagai Suatu Keterampilan Berbahasa. Bandung:CV Angkasa.

Wiriatmaja, Rochiati. (2014). Metode Penelitian Tindakan Kelas. Bandung:PT REMAJA ROSDAKARYA. 